\title{
Meckel's diverticulum on third-generation video capsule endoscopy: intradiverticular ulcer, ectopic gastric mucosa, and active bleeding
}
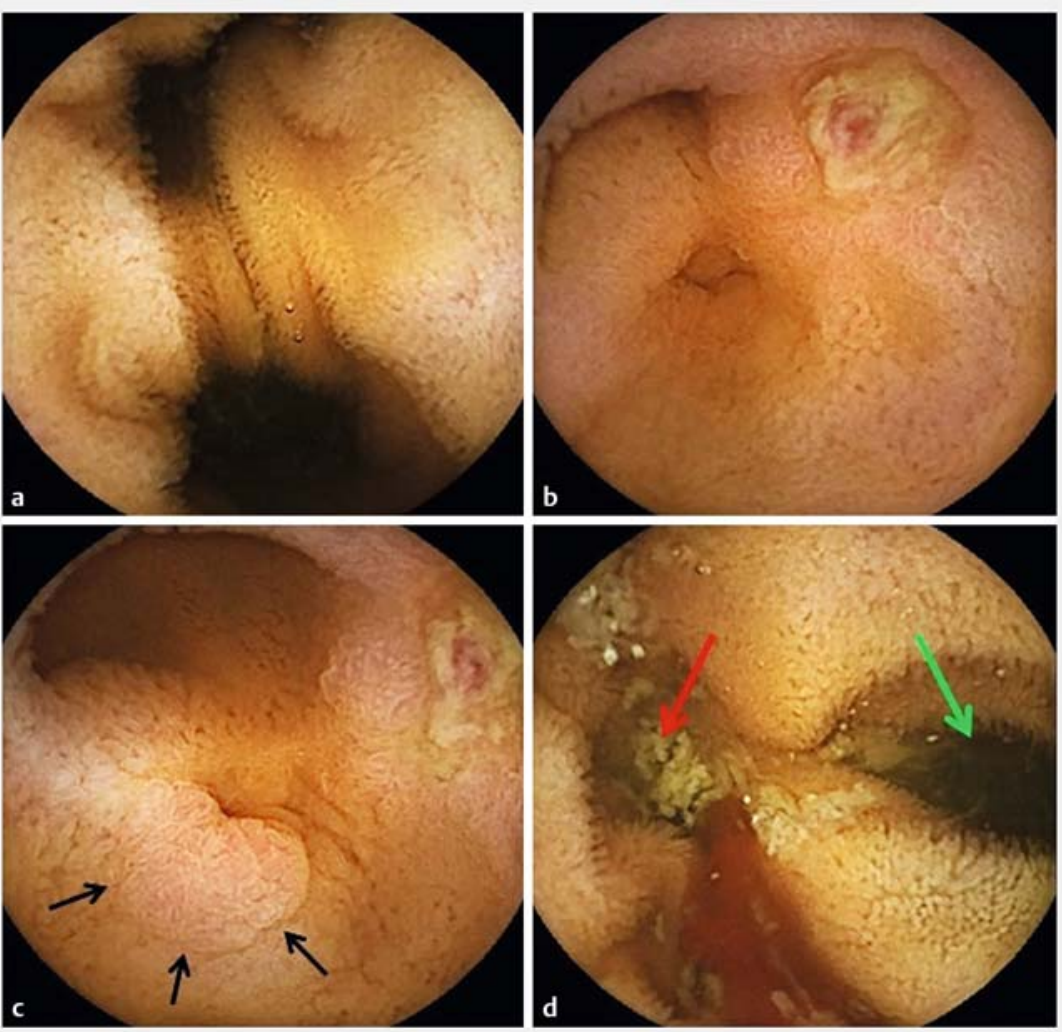

Fig. 1 Images obtained during small-bowel video capsule endoscopy showing: a an ileal diverticular orifice with the double-lumen sign. b ulceration with a visible vessel (Forrest Ila); c ectopic gastric mucosa (black arrows); $\mathbf{d}$ the presence of intradiverticular bleeding (red arrow, diverticular orifice; green arrow, ileum).
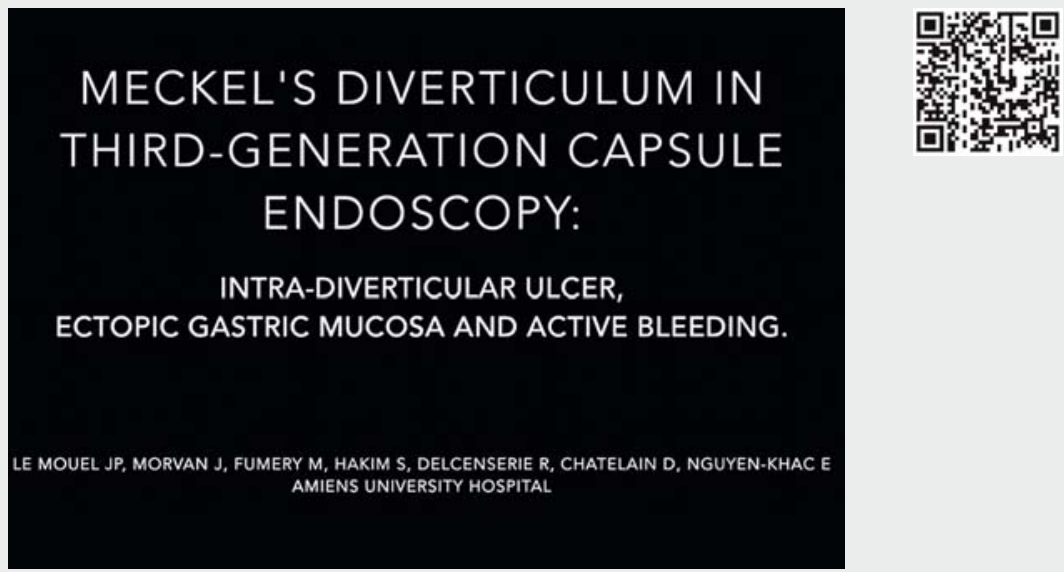

Video 1 Appearances of a Meckel's diverticulum on third-generation video capsule endoscopy.
A 29-year-old man presented with acute rectal bleeding causing hemorrhagic shock. The patient had presented with a similar episode of digestive bleeding 4 years previously, with no diagnosis being found. His physical examination did not reveal any clinical abnormalities. Gastroscopy, colonoscopy, and abdominal computed tomography angiography (CTA) were normal. Small-bowel video capsule endoscopy revealed an ileal diverticular orifice, with the double-lumen sign. After passage of the capsule into the diverticulum, an ulcer with a visible vessel (Forrest Ila) was observed at the bottom of the diverticulum, located next to a patch of heterotopic gastric mucosa. During this examination, active bleeding was seen from this area of ulceration ( $\triangleright$ Fig. 1 ; $\triangleright$ Video 1 ).

A Meckel's diverticulum was suspected. A $99 \mathrm{mT}$ c pertechnetate scintigraphy scan was performed, which confirmed the presence of ectopic gastric mucosa, corresponding to a probable Meckel's diverticulum ( $\triangleright$ Fig.2). Surgery allowed the excision of a diverticulum of $6 \times 2 \times 1 \mathrm{~cm}$ that was found $70 \mathrm{~cm}$ above the ileocecal valve. Histological examination confirmed the presence of ectopic fundal mucosa within the diverticulum ( $\triangleright$ Fig.3). The patient left hospital 3 days after the surgery and has not represented with any further recurrence of bleeding.

Meckel's diverticulum is a vestigial remnant of the omphalomesenteric duct, located on the antimesenteric border of the ileum, within $100 \mathrm{~cm}$ above the Bauhin's valve. About $50 \%$ of symptomatic Meckel's diverticula have been found to contain ectopic tissue, especially gastric mucosa $(35 \%-45 \%)$, which can cause ulceration and hemorrhage; $75 \%$ of hemorrhagic Meckel's diverticula contain gastric ectopic mucosa [1]. Abdominal $C T$ is an insensitive test for detection, especially in adults. In patients with obscure gastrointestinal bleeding, smallbowel video capsule endoscopy is a po- 

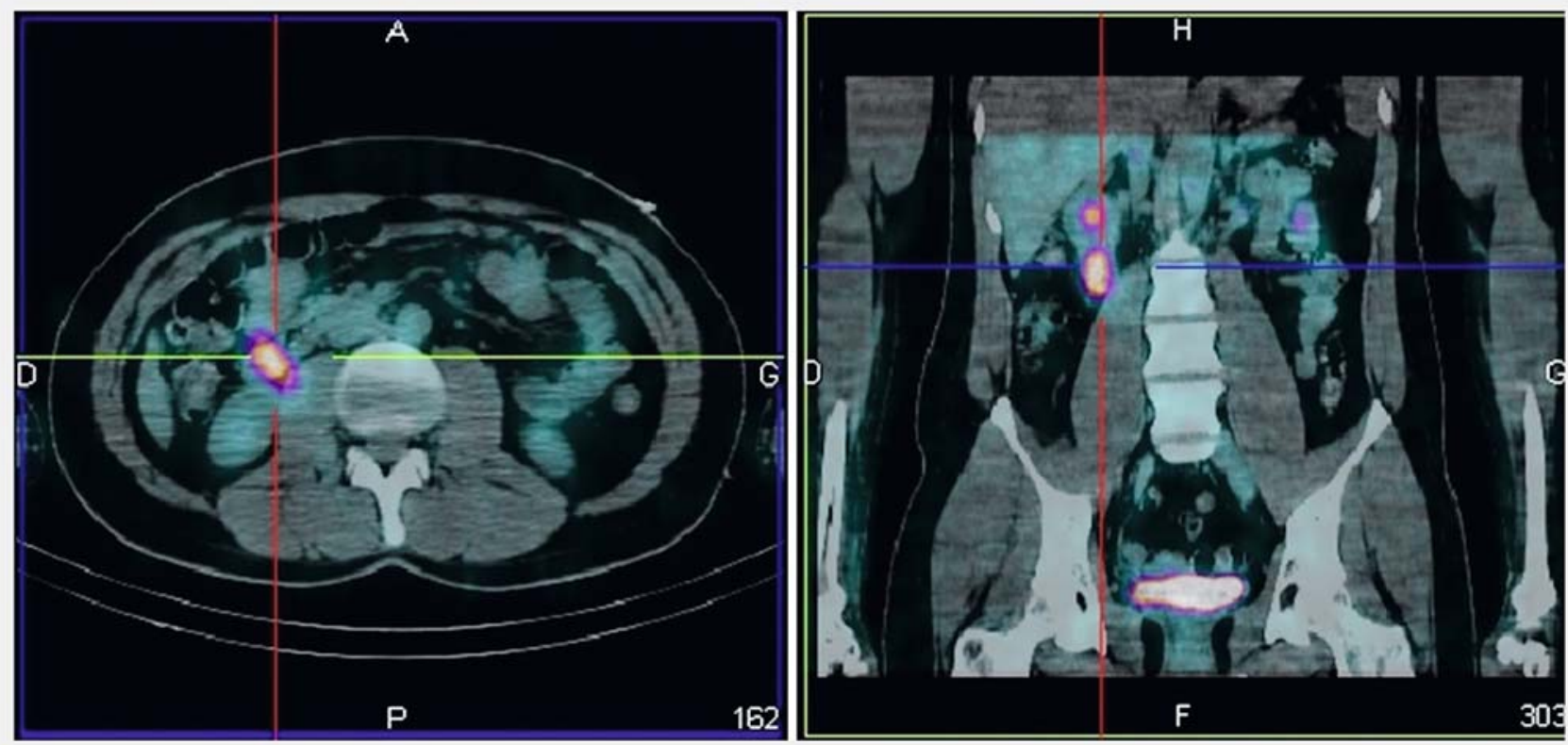

- Fig. ${ }^{99 \mathrm{~m} T c}$ pertechnetate scintigraphy (Meckel's scan) showing ectopically located gastric mucosa.

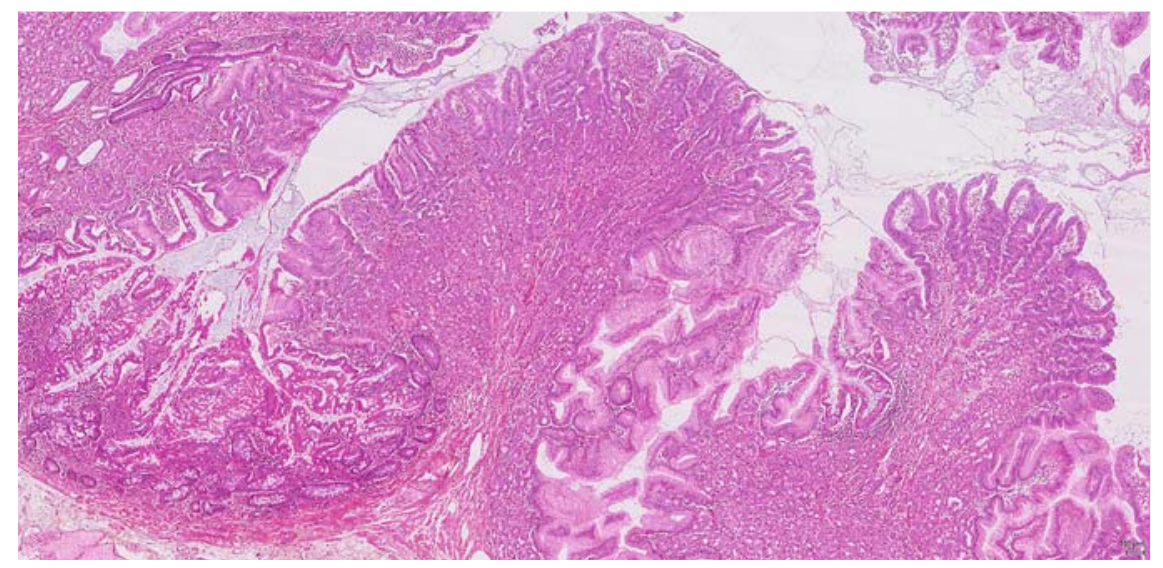

- Fig. 3 Histological appearance on hematoxylin, eosin, and saffron (HES) staining showing ectopic fundal mucosa.

Competing interests

\section{None}

The authors

Jean-Philippe Le Mouel' ${ }^{1}$, Julie Morvan², Mathurin Fumery ${ }^{1}$, Sami Hakim', Richard Delcenserie', Denis Chatelain ${ }^{3}$, Eric NguyenKhac $^{1}$

1 Department of Hepato-Gastroenterology, Amiens University Hospital, Amiens, France

2 Nuclear Medicine Department, Amiens University Hospital, Amiens, France

3 Department of Pathology, Amiens University Hospital, Amiens, France

Corresponding author

tentially interesting test for the diagnosis of Meckel's diverticulum, with a positive predictive value up to $85 \%$ [2]. ${ }^{99 \mathrm{~m} T \mathrm{c}}$ pertechnetate scintigraphy (Meckel's scan), which specifically detects gastric mucosa, is more sensitive in a pediatric population $(85 \%-90 \%)$ than in adult patients $(60 \%)$. This test is particularly effective when there are symptoms related to the ectopic gastric mucosa, such as bleeding [3].

Endoscopy_UCTN_Code_CCL_1AC_2AF

\section{Jean-Philippe Le Mouel, MD}

Department of Hepato-Gastroenterology, Amiens University Hospital, Amiens, France jeanphilippe.lemouel@wanadoo.fr 
[1] Park JJ, Wolff BG, Tollefson MK et al. Meckel diverticulum: the Mayo Clinic experience with 1476 patients (1950-2002). Ann Surg 2005; 241: 529-533

[2] Krstic SN, Martinov JB, Sokic-Milutinovic AD et al. Capsule endoscopy is useful diagnostic tool for diagnosing Meckel's diverticulum. Eur J Gastroenterol Hepatol 2016; 28: 702 707

[3] Elsayes KM, Menias CO, Harvin HJ et al. Imaging manifestations of Meckel's diverticulum. AJR Am J Roentgenol 2007; 189: 81 - 88

\section{Bibliography}

DOI https://doi.org/10.1055/a-0624-1392

Published online: 12.6 .2018

Endoscopy 2018; 50: E205-E207

(c) Georg Thieme Verlag KG

Stuttgart · New York

ISSN 0013-726X

\section{ENDOSCOPY E-VIDEOS}

https://eref.thieme.de/e-videos

口否回 Endoscopy E-Videos is a free access online section, reporting 回和: on interesting cases and new techniques in gastroenterological endoscopy. All papers include a high quality video and all contributions are freely accessible online.

This section has its own submission website at

https://mc.manuscriptcentral.com/e-videos 